\title{
International Actors for Armed Conflict Prevention: A Conceptual Exploration
}

\author{
Jamilah Othman $^{1}$, Azahari Ismail ${ }^{1}$, Jinwon Kim ${ }^{1} \&$ Jeffrey Lawrence D’Silva $^{1}$ \\ ${ }^{1}$ Laboratory of Citizenship \& Leadership, Institute for Social Science Studies, Universiti Putra Malaysia, \\ Malaysia \\ Correspondence: Jeffrey Lawrence D'Silva, Laboratory of Citizenship \& Leadership, Institute for Social Science \\ Studies, Universiti Putra Malaysia, Malaysia. Tel: 60-38-947-1862. E-mail: jld@upm.edu.my
}

Received: July 16, 2013 Accepted: August 21, 2013 Online Published: October 29, 2013

doi:10.5539/ass.v9n15p199 URL: http://dx.doi.org/ass.v9n15p199

\begin{abstract}
The international society is increasingly interested in importance of armed conflict prevention in order to avoid or minimize unnecessary damage. Indeed, many international agents such as the United Nations (UN), non-governmental organizations, and regional organizations maintain efforts and play a major role in field of armed conflict prevention. However, there is little study on which agent play a more effective role as preventer. Based on examination in this article, regional organizations are inherently more likely to embody conditions which help to increase the effectiveness of preventive strategy. Therefore, regional organizations should take initiative, interacting with other international preventive agents and incorporating their actions.
\end{abstract}

Keywords: armed conflict prevention, organizations, United Nations, Cold War

\section{Introduction}

After the end of the Cold War, numerous armed conflicts between/within nations still remain as one of major issues in the international system, exiting and occurring all over the world. Historically, armed conflict is always accompanied by a large number of victims and destruction (Zyck \& Muggah, 2012), but which was often ignored in the past. Indeed, before the end of the Cold War, a main concern of policy-makers and scholars was victory (Wallensten, 2007).

However, development of globalization and humanitarianism and the end of the Cold War attributed to attract their attention on studies of preventing armed conflict (Carnegie Commission on Preventing Deadly Conflict, 1997). Obviously, a large number of innocent people including kids, women and old people as well as military personnel become victims, hurt or killed and suffering from mental damage and poverty resulting from violent confrontation. It also destroys property, resources, environment and economic and cultural development within the conflict area (Rangelov \& Kaldor, 2012). In addition to that, not only it gives an adverse effect on world economy, decreasing trade and investment (Lund, 1996), but also an enormous amount of cost and effort is required in order to rehabilitate nation (Carnegie Commission on Preventing Deadly Conflict, 1997).

Studies on preventing armed conflict have been increased after the end of the Cold War (Wallensten, 2007). Most literature on armed conflict prevention pointed out that there are a wide variety of agents in international system which can play a significant role as armed conflict preventer; states, intergovernmental organizations (IGOs), nongovernmental organizations (NGOs), religious institutions, scientific community, the media, and international business community. However, there is little study on which agent play a more effective role as preventer. Much of armed conflict literature has focused on one or a few cases of a third-party engagement or preventive effort of a single agent, generally the United Nations (UN) (Dixon, 1996). A particular strategy for conflict management or prevention, such as peacekeeping or confidence-building is also one of main topics (Dixon, 1996).

This article first looks at actions and strategies for preventing armed conflict, and then focuses on how to increase the effectiveness of armed conflict prevention. Based on that review, it examines which international preventive agent has inherent features to be more likely to embody condition which contributes to enhance the effectiveness.

\section{How to Prevent Armed Conflict Prevention?}

One of the major goals of the UN is preventing the outbreak of any forms of armed confrontation. Hence the UN 
has discussed and developed strategies and measures for preventing the emergence of armed conflict. In particular, the UN Charters VI and VII focus on preventing armed conflict and peaceful settlement and provide specific preventive methods such as fact-finding, negotiation, enquiry, mediation, conciliation, arbitration, and judicial settlement (Ackermann, 2003).

The UN also used a term for the first time, preventive diplomacy which is the most general term to denote conflict preventions, in a $1960 \mathrm{UN}$ annual report (Ackermann, 2003). Boutros Boutros-Ghali, the former Secretary General of the UN, developed the concept of preventive diplomacy in 1992 and embodied preventive measures such as confidence-building, fact-finding, early warning, preventive deployment, and demilitarized zones (Boutros-Ghali, 1992).

An academic group, the Carnegie Commission on Preventing Deadly Conflict, has more systemically studied and developed the concept and strategies on violent conflict prevention. Generally, the book written by the Carnegie Commission is acknowledged that it has achieved the most influential progress in the field of armed conflict prevention. Notably, the Carnegie Commission (1997) divides the scope of violent conflict prevention into three categories; preventing the outbreak of armed conflict and addressing non-violent methods of dealing with the conflicts, preventing existing hostile conflicts from spreading, and preventing a recurrence of armed conflicts. Based on that classification and the underlying causes of conflict, the Carnegie Commission (1997) developed preventing strategies and classified them into two broad parts, operational prevention and structural prevention. Miall, Ramsbotham, and Woodhouse (1999) also divided preventive measures into two types, light prevention and deep prevention. Light or operational prevention is devoted to prevent ongoing conflict from becoming violent and includes four sub-strategies, early-warning and early-response, preventive diplomacy, economic measures, and forceful measures. On the one hand, deep or structural prevention focuses on conflicts do not occur in the first place, eliminating the underlying roots of armed conflict, and includes three sub-strategies, ensuring security, well-being, and justice. Even though there exists question on whether violent conflict prevention should deal with the underlying roots (Ackermann, 2003), there appears to be an emerging consensus that it is important and should be included in the field of conflict prevention (Hampson, 2002).

In study on preventive diplomacy by Lund (2002), he also proposed preventive actions such as international standard setting, overall institutional arrangements between states, human-rights observers, conditional aid, special envoys, and political dialogue.

\section{Increasing Effectiveness of Armed Conflict Prevention}

One of the major questions commonly identified in the most literature is how to enhance the effectiveness of effort for conflict prevention (Ackermann, 2003; Lund, 2002). Many scholars have struggled to identify how preventive effort is most effective in various situations, focusing on generalization from the lessons learned from case studies on failures of prevention.

Lund (2002) identifies four factors increasing effective prevention; timing of third-party action, appropriate engagement fit into specific situation, adaptation of various strategies, and aids by global and regional actors. He also emphasizes that it is impossible to formulate ways for conflict prevention because every conflict situation is always different, dynamic, evolving, and flexible. Ackermann (2003) synthesized through review of previous research that preventive action is likely to be more effective under conditions; timely preventive action, use of various preventive methods, capability to support strategies or assistance from major international actors, and cooperation with other preventive actors. Timely and appropriate preventive actions are also emphasized by Zartman (2001, p. 10), pointing out that "doing the right thing at the right time" is best work for prevention. Cockell (2002) stresses that preventive effort should be designed based on specific conflict settings. In order to make such an effort effective, he proposes that conflict preventer first should analyze conflict situation and available instruments for prevention, and then monitor and evaluate the effect of preventive action employed. During this process, more significantly, he mentions that available preventive measures should be integrated and actions by preventers should be coordinated. Institutionalization of preventive strategies and policies is another important factor for enhancing effective prevention. In particular, Ackermann (2003, p. 344) emphasizes that international preventive actors including intergovernmental and nongovernmental organizations, and countries should make an effort to incorporate international policies related to armed conflict prevention and "to operationalized across a joint group of preventive actors".

\section{Most Appropriate International Agent for Increasing Effectiveness}

Despite a large number of studies on increasing the effectiveness of preventive action, no one practically guarantees which strategy will be effective on a specific conflict situation. In this context, it is particularly worth looking into which agent is inherently most appropriate so as to embody conditions which help to increase the 
effectiveness of preventive effort mentioned above. According to the Carnegie Commission (1997), agents for preventing violent conflict are as follow; nation-states and their leaders, nongovernmental organizations (NGOs), religious leaders and institutions, the scientific community, educational institutions, the media, international business community, the UN, and regional organizations.

First condition to enhance the effectiveness of prevention is timing of third-party action. Clearly, timing is closely related to geographical proximity with conflict area (the Carnegie Commission, 1997). That means that preventer which is closer to conflict area is less likely to miss timing of preventive action. Furthermore, to take action timely, decision should be made rapidly and the action should have impact toward actors involved conflict. If decision-making process is complicated and takes long time, it may be difficult to take preventive action at the proper time. In short, agent, which is geographically closer to conflict area, able to make decision quickly, and able to take a wide range of influential actions, is more likely to take action timely. In this sense, actions taken by NGOs, the scientific community, educational institutions, and the media might be less influential than others, particularly in imminent crisis, and are relatively limited compared to other agents. In other words, these agents have capability to implement early-warning and fact-finding, whereas they have limitation to carry out some preventive strategies such as preventive diplomacy and economic measures. Probably, the UN employs all kind of preventive strategies and the most influential action, but has weakness in geographical distance and decision-making process compared with regional organization and nation-state located in conflict area. Since it is practically impossible for the UN to cover all conflicts occurring and ongoing over the world, it should focus on preventing conflict which can bring out large-scale damage such as Rwanda genocides (UN, 2001). On the contrary, regional organization and nation-state located adjacent to conflict area have strength in distance (Miall, Ramsbotham \& Woodhouse, 1999) and are more likely to rapidly make decision because the outbreak of armed conflict directly impacts regional security. For maintain regional security, two agents would actively make more efforts and call for help to the UN if they need some actions which is beyond their capability.

Second condition to enhance the effectiveness of prevention is appropriate engagement fit into specific situation. In order to do so, preventer should know not only conflict situation and underlying causes, but also political, economic, cultural, ethnic, and even religious features of claimants. Actions based on strategies adopted after preventer fully understand and consider these features are more likely to be accommodated by claimants without reluctance and also less likely to cause negative effect or another conflict. In this regard, nation-state and regional organization in conflict region have more strength in terms of taking action fit into specific situation. In particular, regional organization in which claimants are members might have more advantage than nation-state. Anderlin, and Victoria (2008) also points out that local actors are often best placed to understand conflict due to familiarity with their region and cultural context. If preventive actor fully understands and considers underlying all features noted above of respective claimants, it could analyze conflict situation.

In terms of adaptation of various strategies for preventing armed conflict, the UN may be the strongest actor. With greater capability and various preventive strategies, it has been playing a crucial role such as peacekeeping operation, preventive deployment, assistance for human right and development, and humanitarian aids (UN, 2001). However, it is notable that nation-states, regional organizations, and NGOs can use of UN's capability by calling for UN's help.

In order to carry our sustainable preventive action, preventive actor should have sufficient resources and capacity, for example finance, or obtain support from major international actor. Since the objective of the UN is to ensure international peace, it would be undoubtedly the most appropriate actors. Regional organizations are also important in this regard because it has adequate capability in leadership, finance, and institutional system and their objectives can be achieved under regional peace and stability no matter what objectives of establishment are. However, other actors such as NGOs, the scientific community, educational institutions, and the media has limitation in finance and capability to continuously implement preventive action even for a long time.

Cooperation among different preventive actors and combination of various methods is the last condition identified. To initiatively do so, preventive actor should have political leadership. In this sense, NGOs, the scientific community, educational institutions, and the media has weakness in terms of taking initiative in coordinating and conducting multilateral actions taken by the UN, regional organizations, and nation-states. According to Ackermann (2003), this condition is encouraged through institutionalization of preventive strategies and prevalence of international culture of armed conflict prevention, emphasizing that preventive action incorporating in the regional organizational level is the most ideal when considering legitimacy of preventive strategy and ability to incorporate and implement multilateral preventive actions. 


\section{Conclusion}

The international society is increasingly interested in importance of armed conflict prevention in order to avoid or minimize unnecessary damage (Ackermann, 2003). Indeed, many international agents such as the UN, NGOs, and regional organizations maintain efforts and play a major role in field of armed conflict prevention. However, there have been several cases that these preventive efforts and actions fail to prevent the outbreak of armed conflict or unintentionally yield even negative outcome at times. Hence, increasing effectiveness of preventive strategy is one of major issues in conflict prevention.

As explored in this article, regional organizations are inherently more likely to embody conditions which help to increase the effectiveness of preventive strategy. Although the UN is strong agent for prevention, regional organizations have more strength in timing of action, country context-specific, and coordination of multilateral actions and strategies. Of course, compared with the UN, regional organizations have limitation in capability conducting various strategies and actions and sufficient resources, it can be simply overcame by requesting help. Other international preventive agents such as NGOs, educational institutions, and the media are also important, but have limitation in taking initiative due to lack of political leadership. Therefore, to enhance the effectiveness of preventive strategy, regional organizations should take initiative, interacting with other international preventive agents and incorporating their actions. Wedgwood (1996) also emphasized five advantages of regional organizations in conflict management: rapid action; facilitating to build confidence; avoiding to raising unnecessary tensions; preventing misperception among conflict parties; and minimizing mistakes such as condescension or colonialism. Charter of the UN, Chapter VIII, also explicitly highlight the importance of regional organizations and arrangements and encourages their development. There need further empirical studies on this argument.

\section{References}

Ackermann, A. (2003). The Idea and Practice of Conflict Prevention. Journal of Peace Research, 40, 399-347. http://dx.doi.org/10.1177/0022343303040003006

Anderlin, S. N., \& Stanski, V. (2008). Conflict Prevention. Retrieved June 10, 2012, from $\mathrm{http} / /$ international-lert.org/sites/default/files/library/TKConflictPrevention.pdf

Boutros-Ghali, B. (1992). An Agenda for Peace. Retrieved June 7, 2012, from http://www.un.org/Docs/SG/agpeace.html

Carnegie Commission on Preventing Deadly Conflict. (1997). Preventing Deadly Conflict: Final Report. Washington, DC: Carnegie Commission on Preventing Deadly Conflict.

Charter of the United Nations, Chapter VIII. (n. d.). Retrieved June 15, 2012, from http://www.un.org/en/documents/charter/chapter8.html

Cockell, J. G. (2002). Planning Preventive Action: Context, Strategy, and Implementations. In Hampson \& Malone (Eds.) (2002), From Reaction to Conflict Prevention: Opportunities for the UN System. Boulder, CO: Lynne Rienner.

Dixon, W. J. (1996). Third-party techniques for preventing conflict escalation and promoting peaceful settlement. International Organization, 50(4), 653-681. http://dx.doi.org/10.1017/S0020818300033543

Hampson, F. O. (2002). Preventive Diplomacy at the United Nations and Beyond. In F. O. Hampson \& D. M. Malone (Eds.) (2002), From Reaction to Conflict Prevention: Opportunities for the UN System. Boulder, CO: Lynne Rienner.

Lund, M. S. (1996). Preventing Violent Conflicts: A Strategy for Preventive Diplomacy. Washington, DC: Institute of Peace.

Lund, M. S. (2002). Preventing Violent Intrastate Conflicts: Learning lessons from Experience. In P. van Tongeren, H. de Veen \& J. Verhoeven (Eds.), Searching for peace in Europe and Eurasia: An Overview of Conflict Prevention and Peace-building Activities. Boulder, CO: Lynne Rienner.

Miall, H., Ramsbotham, O., \& Woodhouse, T. (1999). Contemporary Conflict Resolution. Cambrige: Polity Press.

Rangelov, I., \& Kaldor, M. (2012). Persistent Conflict. Conflict, Security \& Development, 12(3), 193-199. http://dx.doi.org/10.1080/14678802.2012.703531

United Nations, General Assembly, Security Council. (2001). Pervention of Armed Conflict: Report of the Secretary-General. 
Wallensteen, P. (2007). Understanding Conflict Resolution: war, peace and the global system (2nd ed.). London: SAGE.

Wedgwood, R. (1996). Regional and Subregional Organizations in International Conflict Management. In C. A. Crocker, F. O. Hampson \& P. Aall (Eds.), Managing Global Chaos: Sources of and Responses to International Conflict (pp. 275-285) Washington, DC: United States Institute of Peace.

Zartman, W. I. (2001). Preventive Diplomacy: Setting the stage. In W. I. Zartman (Ed.), Preventive Negotiation: Avoiding Conflict Escalation. Oxford: Rowman and Littlefield.

Zyck, S. A., \& Muggah, R. (2012). Preventive Diplomacy and Conflict Prevention: Obstacles and Opportunities. Stability: International Journal of Security and Development, 1(1), 68-75. http://dx.doi.org/10.5334/sta.ac

\section{Copyrights}

Copyright for this article is retained by the author(s), with first publication rights granted to the journal.

This is an open-access article distributed under the terms and conditions of the Creative Commons Attribution license (http://creativecommons.org/licenses/by/3.0/). 